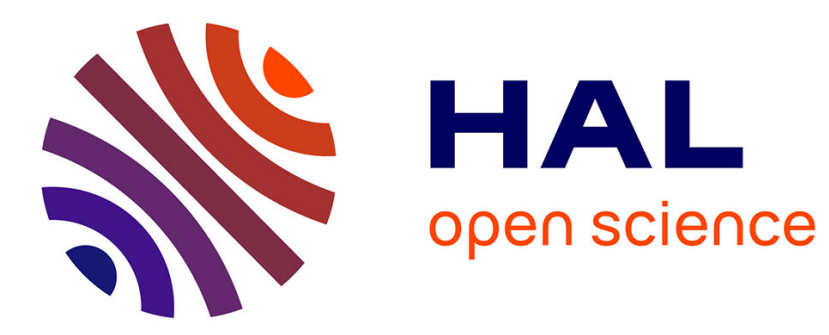

\title{
Lévi-Strauss's heroic anthropology facing contemporary problems of the modern world
}

\author{
Albert Doja
}

\section{To cite this version:}

Albert Doja. Lévi-Strauss's heroic anthropology facing contemporary problems of the modern world. Reviews in Anthropology, 2020, 49 (1-2), pp.4-38. 10.1080/00938157.2020.1794140 . halshs02970263

\section{HAL Id: halshs-02970263 \\ https://shs.hal.science/halshs-02970263}

Submitted on 22 Nov 2020

HAL is a multi-disciplinary open access archive for the deposit and dissemination of scientific research documents, whether they are published or not. The documents may come from teaching and research institutions in France or abroad, or from public or private research centers.
L'archive ouverte pluridisciplinaire HAL, est destinée au dépôt et à la diffusion de documents scientifiques de niveau recherche, publiés ou non, émanant des établissements d'enseignement et de recherche français ou étrangers, des laboratoires publics ou privés. 


\title{
Lévi-Strauss's heroic anthropology facing contemporary problems of the modern world
}

\author{
Albert Doja (D)
}

\begin{abstract}
Claude Lévi-Strauss, the founder of the structural revolution in anthropology, passed in October 2009. In the decade after his death, we are presented with a significant number of successive publications that celebrate both his work and life and the ever-lasting public engagement of his heroic anthropology with problems of the modern world. This extended review article is focused to deal with these works in relation to contemporary issues, which is not already so well known for LéviStrauss and which can make a point to restore him to a central position of importance not merely in the history of anthropology but also in the public engagement of current anthropology.
\end{abstract}

\section{KEYWORDS}

Claude Lévi-Strauss (1908-2009); public anthropology; structural legacy in anthropology; current issues in anthropology; social ontology; biopolitics; morphodynamics

\section{The view from afar on modernity}

With the continuous celebrations of the great man and last giant of French thought, we have also been presented with the celebration of two grand narratives of his work and his life (Godelier 2013; Loyer 2015), acclaimed by the French press as an unparalleled methodical inventory of LéviStrauss's works and a definitive biography of his life, respectively. These massive biographical tomes may be characterized "as Left Bank versus Right Bank books" (Harkin 2019, 88-89). They may also be read, as LéviStrauss himself might have put it, like a Parisian fashion which changes every 5 years and already has had its 5 -year rotation (Doja 2020). In turn, in this case as in others, Lévi-Strauss himself would probably express himself better than any of his many commentators. The aim of this review essay is precisely to assess a significant number of recent publications of his collected essays/lectures, which allow to better grasp the evolution of his thinking over the years.

Lévi-Strauss's life and work bore heavily the imprint of contingent forces, and he went through the twentieth century by cultivating a constant conflicting relationship with modernity. Structural anthropology was not only, 
as is often narrated, the product of an isolated genius and his clever idea to apply linguistic approaches to the study of culture, but the culmination of a process of participation in the intellectual reconstruction effort of postwar society, which extended Durkheim's sociological method by means of structural linguistics. The method of structural anthropology that revolutionized human sciences and overturned our conception of humanity was the result of a work in exile and the product of a world in crisis, which made LéviStrauss to give up a whole part of his youth political illusions. As Foucault wrote, it was "the awakened and troubled consciousness of modern thought" (Foucault 1966, 221 [Eng.208]), which not coincidentally emerged in the day of reckoning of the colonial empire. A trait peculiar to the founder of structural anthropology, which some might see as either a "hatred of the West" or a "hatred of the Self," should rather be seen as a criticism or a "dissolution" of the Western subject.

Lévi-Strauss has been often criticized for reducing cultures to logical forms, but he never downplayed individual autonomy, announced the death of the author, or shut himself away in the ivory tower. In a number of his early texts, readings, interviews, correspondences, and musings recently published in several successive collections (Jakobson and LéviStrauss 2018; Lévi-Strauss 2011a, 2011b, 2013, 2015, 2016a, 2016b, 2019), we see the author at work, showing that structural anthropology was in his eyes a detour to return critically to the society of his time. The acuteness of these posthumous pages does not only lie in the "zero signifier" of structural anthropology, but also in the importance of his traditional nonconformism, claiming his distantiation by a "view from afar" that cast a subversive look on modernity.

Lévi-Strauss's peculiar "view from afar" has queried contemporary issues that remain astonishingly timely and topical. A prehistory of structural anthropology is restored at its "zero point" in texts written and published in the 1940s (Lévi-Strauss 2019), or in his tribute to Montaigne (LéviStrauss 2016a), while he had not yet abandoned his political reflections. After his 1952 and 1971 Unesco essays on racism (Lévi-Strauss 2002), his Lectures at the Ishizaka Foundation in 1986 were admittedly a third, theretofore unpublished, exposition of his view on the contemporary world (Lévi-Strauss 2011a). He addressed here the major themes of his anthropology, including the very contemporary questions posed by the advent of new biomedical reproductive technologies, the model of Western economic development compared to other conceptions of society studied by anthropology, and the crisis that Western knowledge was beginning to experience in terms of its authority. ${ }^{1}$ In turn, his occasional papers on Japan in the 1980s and 1990s show his admiration for a country that has taken up the challenge of contemporaneity while preserving its multi-centuries heritage 
by the constant oscillation between closure at self and openness to others (Lévi-Strauss 2011b). He also addressed media events with lucidity, since at least the early 1950s (Lévi-Strauss 2016b) and through a series of chronicles written in the 1990s for the Italian daily La Repubblica (Lévi-Strauss 2013). Often he is held in a certain methodological withdrawal, refusing the posture of the committed intellectual of his time, but he metamorphosed here into a remarkable chronicler commenting on the news and casting his view from afar on the great questions that agitate our time.

Despite the French Series Editor's claims, probably none of these collections is an "introduction” to Lévi-Strauss's work in terms of theorization and method. The earlier texts are a prehistory of structural anthropology, the Japanese lectures probably have no testamentary value, and they add little to our understanding of Lévi-Strauss's thought. If the writings on Japan are simple and accessible, they do not provide much detail either, and Japan remains as distant as an ultimate symbol of otherness. The Italian chronicles also remain poorly organized, and apart from the implied common themes, the Editors have not succeeded in drafting a logical thread between these collections, while concepts, examples, and whole paragraphs are often repeated in the various writings.

For some, in spite of his habitual clarity of style, sometimes Lévi-Strauss seduces and amuses sometimes he irritates and horrifies. One is probably repelled and discouraged by some relatively conventional considerations at formal speeches in Japan, where he seemed secretly haunted by a need for conformity and compliance, deliberately leaning toward the conventional and diplomatic views of a knowledge established by public authorities. For others, his views seem resolutely turned toward the past, without being interested in the social reality of contemporary Japan, believing that cultural borrowings have been "carefully filtered" (Lévi-Strauss 2011b, 54 [Eng.40]), in order to preserve a Japanese specificity that would be dehistoricized and idealized (Laplantine 2012, 300). Yet for others, the political and the ethical stakes of Lévi-Strauss's views on cultural diversity as a necessary human resource remain dependent on a degree of ethnocentric pride and prejudice (Kuper 2013), and his conservatism and moral relativism come to the fore in a stark and troubling way (McLennan 2016). Again and again, in his thoughtful exercises, Lévi-Strauss seems all too inclined to fit his perceptions of Japanese culture, however astute, into reductionist schemas of affinities and oppositions, which reduced his structural approach to the level of a parlor game (Launay 2013, 42-43). He seemed to address relativistic problems with fundamentally Cartesian ideas, firmly planted into the binaries of us/them, modern/other, the-people-we-are/thepeople-we-study, which are supposed to reveal his own mind forever trapped to lag behind the ontological turn. 
These collections may not provide an overwhelming scholarship and may not bring anything new to Lévi-Strauss's structural method. Yet, they offer a telling portrait of the intellectual captivation and curiosity of a pivotal figure in the history of anthropology, and they bring out the deep structure of his thought, which inspired the wonderful body of his work on kinship, classification systems, mythology, the human condition, and structural methodology. They illuminate the zeal that motivated Lévi-Strauss's anthropological work and they shed a new light on the constructed image of Lévi-Strauss as a "disengaged" scholar, observing humanity from above and from afar.

The earlier texts show a Lévi-Strauss at once political and optimistic, at any case with a certain faith in the human capacity to change the course of history. He seems to be a young man of the Left, dreaming of a new world order that anthropology could help building at international and local level. His latest writings reveal him falsely modest, but an enthusiastic free thinker who dared to formulate dazzling propositions. Some themes resonate terribly with current societal debates, after which media events can no longer be considered as before. Instead of providing what has been irreverently claimed to be a "scant guidance" to the alleged "problems that can be blamed on our expulsion from Eden" (Kuper 2013), he converted the theoretical and methodological insights of structural anthropology into events for thought, making them a concern for all.

These collections address in some way the vexing questions of the dual perspective of rationalism/relativism and the construction of a critique of ethnocentrism through a clever and elegant comparison of a series of analogies between parallel mythologies, histories, customs, practices, or attitudes, including the ability to address heterogeneous and contemporary issues. Far from the asceticism of scholarly works, they offer a panorama of the possibilities of structural thinking and force us to reflect on major issues in anthropology. They may not propose solutions to the problems of modernity, but they raise questions where there seem to be none and they modify the terms and the perspective of the questions we ask. They provide us new opportunities to consider the problems differently and to displace the vision of our actual situation in the contemporary world.

In the earlier texts, Lévi-Strauss constructed objective models of social relations from the relationship between "war and trade" in indigenous societies, offering us a lesson of the "foreign policy of a primitive society" between a few straw huts (Lévi-Strauss 2019). These texts, in their diversity and their internal coherence, make it possible to understand in what terms Lévi-Strauss spoke of the catastrophe long before it was named and in what sense Amerindian societies provide models for thinking about the current ecological crisis (Keck 2019). In the Japanese lectures, Lévi-Strauss 
returned to the definition of anthropology, its epistemological status and method, confronted with the challenges facing the contemporary world, which it may help to understand and resolve (Lévi-Strauss 2011a). In the writings on Japan, there is almost an application of his scientific approach which he illustrated by metaphorically characterizing a fascinating, deep and mysterious Japan, as "the other side of the moon," a kind of symmetrical equivalent of Western culture, where daily and millennial gestures are the same, but inversed (Lévi-Strauss 2011b). Similarly, the Italian chronicles refer quite dramatically to the notion finely and intelligently posited by Montaigne in his essay on the Cannibals: "everyone gives the title of barbarism to everything that is not in use in his own country" (Essays 1.31; cf. Lévi-Strauss 2016a, 76-77). Lévi-Strauss starts each time with a topical media event to draw general conclusions on the course of the world and the lessons of history and anthropology, in resonance with more personal and broader historical, philosophical, and anthropological reflections (LéviStrauss 2013).

In some of these writings, Lévi-Strauss offered unusual reflections on contemporary themes such as Christmas traditions, the specificities of Japanese culture, the ritual practices of excision and circumcision, the symbolic meaning of jewelry and metals, the resurgence of avuncular relations at the funeral of Lady Diana, or the similarities between mythological models and the interpretative quandaries of modern physics. In some chapters, he is concerned again with the rise of agriculture and Western-style development, or the human condition and the productivity of the market economy. Genetic studies permeate other chapters, where he takes hold of the key concepts of cultural heritage and genetic heritage to reformulate his earlier incisive contributions to the politics of race (Lévi-Strauss 2002). Yet in other chapters, his focal point of analysis moved to issues of the body and society inside of our own racially prejudiced societies, such as female sexuality and the origin of modern human sociality, AIDS epidemic, mad cow disease and cannibalism, genital mutilation, medically assisted procreation and homosexuality, or marriage and family structures. They all show that the Far East and the West, the primitive and the modern, the old and the new, the distant and the near, the sacred and the profane illuminate each other. With an impressive precision, he was once again sowing disquiet into the confused categories of barbarism and civilization whose obscure intertwining he never stopped exploring. These texts reveal how the thoughts of Others from other places enrich us much more profoundly than blinkered thinking could ever do.

We see clearly in these collections how the crucial problems of globalization, overpopulation, environmental degradation, and the proliferation of material and immaterial flows became Lévi-Strauss's main preoccupations, 
as did "the affinities between the various ideological explosions and the development of different forms of fundamentalism" (Olender in LéviStrauss 2011a, 10 [Eng.X]). Already in the midst of the glorious thirty, in his flagship book Tristes Tropiques (Lévi-Strauss 1955), which for many scholars provides the best understanding of Lévi-Strauss and his thought (see Doja 2008b), Lévi-Strauss had long and forcibly denounced the ravages of technological progress and the expansion of a model of civilization that is still destroying both human societies and natural environments. If anything, the range of his concern widened, from all cultures to all living species. The world is endangered, he was increasingly convinced, by a rapidly expanding and increasingly culturally uniform human population that is mindlessly driving other species to extinction. By shifting his attention from the historical moment of his cultural encounter in the Brazilian field to contemporary ecological and political debates, Lévi-Strauss's structural analysis as a method and a scientific contribution became a vibrant environmental advocacy before the concept was even invented. It is not sufficiently understood that Lévi-Strauss was a profoundly ecological thinker. His critique of a "corrupt" humanism that places "Man" above other living beings, is now more relevant than ever. Not surprisingly, his discourse will be hardened over the years as he unrelentingly and uncompromisingly returned to it repeatedly.

Any reader of Lévi-Strauss may be struck today by the fulgurant prescience of his ideas and positions which remain exemplary. Even highbrow ideas of our days, such as the creation of a ritual and symbolic atmosphere to address climate change as part of the Paris COP21 negotiations (Latour 2015), the Holocene resurgence of a multi-species model countering the proliferation of polluted forms of life in the Anthropocene "plantation" (Tsing 2015) or the accelerated change of global modernity in terms of "overheating" (Eriksen 2016), parallel Lévi-Strauss's insights, which are often thought in the mind of today authors, at best, without their being aware of the fact. ${ }^{2}$

At a distance from the French and Western parochial debates that reduce humanism to consciousness, he insisted again on the necessity for the advent of a new generalized humanism that should be open and multipolar, democratic and contemporary, because "nothing human can be alien to humankind" (Lévi-Strauss 2011a, 49 [Eng.36]). Concerned with the perception of ourselves as prisoners of a self-centered gaze, he redefined anthropology as a discipline devoted to the study of human experience in all its social, institutional, and symbolic dimensions, including contemporary issues within the framework of a historical past and a disturbing exoticism. He sought to understand social facts according to their place in society and he highlighted very clearly the principle that they must be explained in 
their historical and cultural context, through a differential contrast where the distant and the proximate are constantly echoing each other.

Defender of cultural diversity, sometimes with a subtle and ironic paradox, Lévi-Strauss endeavored to recognize and theorize what is original in a culture and he insisted to define anthropology by its preference for studying "authentic" societies and ethnography by striving for its own authenticity, by which he meant an appreciation of these societies in their own terms. He also remained of a rare and formidable intellectual honesty. In all fairness, he did not choose to publish these musings and their urbanity and even relative superficiality were perhaps appropriate for the occasion (Launay 2013, 43). In turn, they reveal the challenge of Amazonian societies or Japanese culture and history, which after all he knew little about but allowed him to develop very stimulating intercultural comparisons based on the construction of a system of invariant differences. In his case, the objectivity of anthropology could not exhaust itself in the observation and description of properties and curiosities of exotic cultures. To make a valid judgment about any culture, one ought to escape the magnetic attraction of every culture. "Only on that unrealizable condition could we be assured that the judgment is not dependent either on the culture being examined or on the observer's culture, from which the observer cannot consciously or unconsciously detach himself" (Lévi-Strauss 2011b, 15 [Eng.3]). By the very act of observing others anthropologists introduce alien concepts and notions into their own way of thinking.

In this sense, Lévi-Strauss built his "view from afar" not only on the insight that "no portion of humanity could aspire to understand itself except with reference to others" (Lévi-Strauss 2011a, 46 [Eng.33]), but also on the very distance that separates anthropological observers from the societies they choose to observe. To estimate and assess that distance, anthropologists must adopt a perspective that places them outside their own cultural tradition without ceasing to be inside it, while trying to enter into the most intimate essence of the observed culture that will always remain inaccessible to them. Similarly, "to know and understand one's own culture, it is necessary to regard it from the point of view of another" (Lévi-Strauss 2011a, 44 [Eng.30]). In other words, he constructed a doubly distant view, removed both from other cultures and from one's own culture. Finally, he argued that what is constitutive of the object and the very method of anthropology is a "technique of displacement (dépaysement)" (Lévi-Strauss 2011a, 45 [Eng.31]), ${ }^{3}$ where distantiation, disorientation, estrangement, defamiliarization, and alienation do not lend enchantment to the view but put in question the dogmas taken for granted in the contemporary Western World. 


\section{Zero signifier of structural anthropology}

The texts collected in Structural Anthropology Zero (Lévi-Strauss 2019) are written and published in the 1940s, before the structural analysis method were implemented in the Elementary Structures of Kinship first published in 1949 (Lévi-Strauss 1967) and fully theorized in Structural Anthropology (Lévi-Strauss 1958). If the earlier contributions were neglected and were not included in Lévi-Strauss's theoretical collections while he was alive, they are nevertheless not too descriptive or anecdotal, but they form a coherent whole. These texts mark the way in which Lévi-Strauss became involved in the current events of war and postwar years. They situate the emergence of structural analysis, not in the 1960s as it is often believed (reducing it to structuralism as a kind of intellectual fashion), but very early when the ethnography of remote areas was coupled with a structural anthropology called by the events of the postwar period. More than anything else, the term "zero" is a way of bringing structural analysis back to its original context.

On the one hand, it resonates with a number of formulas that marked the postwar period, such as "man at point zero" used to designate the survivors of death camps, ${ }^{4}$ or "hour zero" (Stunde null) used to tag the collapse of Nazi Germany in 1945 as in Roberto Rosellini's movie Germany Year Zero featured in 1948. This term "crystallizes fundamentally contradictory historical connotations, which certainly denote rebirth and recommencement, but also the horror and the unthinkable" (in: Lévi-Strauss 2019, 51). These texts are marked by the experience of exile and attest to a biographical and historical moment in which Lévi-Strauss is a refugee in New York, like many European Jewish artists and scholars. In these years, the awareness of irreparable historical catastrophes led Lévi-Strauss to a disillusioned conception of social and political life. The prehistory of structural anthropology underlines the feeling of tabula rasa, which animated Lévi-Strauss at the end of war, and the project of a civilizational renewal on new bases. But this imperative also emerged against a backdrop of anguish and fear. The neglected texts of the 1940s suggest in a striking way that the birth of structural anthropology is deeply linked to the presentiment of a tragic awareness that civilization carries within itself the germ of its own annihilation. The analogies between the extermination of American Indians, the genocide of the European Jews in death camps and the coming ecological catastrophe bring a frightening confirmation to such apprehension.

On the other hand, the term "zero" also refers to a linguistic theory about the emergence of meaning from meaningless elements popularized by Roland Barthes in his Writing zero degree (Barthes 1953), at any case about signifiers without the materiality of linguistic labels and objects that 
are used to absorb or neutralize a meaningful opposition. The notion of such "floating signifier" that is said to possess symbolic value "zero" originated in Lévi-Strauss's Introduction to the work of Marcel Mauss (LéviStrauss 1950, 49), and has been from the start at the very foundation of structural analysis (Jakobson and Lévi-Strauss 2018). The models of social relations between "war and trade" and the lesson of "foreign policy of a primitive society" show how the strength of indigenous societies is contrasted with the weakness of Western societies. The former have been able to recognize and ritually organize the antagonisms, while the latter deny them under the dream of a neutral life without embarrassment and without restraint on their exchanges. They run the risk of not being able to "absorb the extreme variations that may occur" in the balance of society, thus allowing our fears to be rationalized and politicized by some sinister appropriation. Lévi-Strauss then wondered whether "the point of view of 'closed' societies could allow access to a spiritual wealth and a density of social experience of which we would be wrong to let dry out the source and lose the teaching" (Lévi-Strauss 2019, 219).

His later contributions gradually bring to light the disasters that made possible his own encounter with these societies, so that the subjectivity that resulted from these disasters became a movement of reflection and a ground of comparison on the notion of disaster itself. For Lévi-Strauss, it cannot be thought in itself but only in the relations that it allows to establish with other disasters that occur at different levels. What spontaneously presents itself as an entanglement of unpredictable events was described retrospectively as structural levels that are linked to each other by semantic operators (Keck 2019). The collapse of the Amerindians referred to the long-term consequences of Neolithic and Industrial Revolutions that are thought more objectively by means of structural analysis. The detour by Amazonian societies allowed Lévi-Strauss to grasp the meaning of the Holocaust and the extermination of the Jews in Europe, which referred back to a catastrophic European event that concerned him closely in his own subjectivity.

If the use of the term first denoting a punishment of a natural misfortune has been criticized when applied to an exclusively human barbarism (D'Onofrio 2018, 19), this connection constituted an essential conceptual resource, which could not be relegated to a singular moment in history, but seeks primarily to link together the ideas of natural disaster and human crimes. Probably, the experience of the partition of South Asia between India and Pakistan, as an intermediate historical event from which an awareness of social conflict became possible, might have lead Lévi-Strauss to understand in retrospect that in all cases the destruction of one part of humankind by another occurred because it made impossible the conditions 
of life in common. He then included the catastrophes in a longue-durée temporal arc, from the invasion of Amerindian territories to the industrial revolution in Europe, turned against itself and against its own population. In 1973, when he received Erasmus Prize, Lévi-Strauss associated, in the same denunciation, the abuses of Western civilization, the collapse of indigenous populations, the death camps and the destruction of animal and plant species, which seemed announcing the effects of a global ecological disaster (D'Onofrio 2018)..$^{5}$ A single root cause of disasters would be, in effect, the inability of Western civilization to impose a limit on its own power.

Lévi-Strauss defined Western civilization in a way that shows it presiding over the relations of humans to each other in the form of a quest for domination that can culminate in genocide and crimes against humanity. It is also reflected in the relationship of humans to nature in their project of making themselves masters and owners of nature, which is based on forgetting that the human being is a living among others. He reminded that "the Western man, by arrogating to himself the right to radically spoil humanity from animality, by granting to the one all what he refused to the other, he was opening a cursed vicious cycle." The dark portrait of Western civilization mirrored the praise of peoples whom the West attributed a primitive character, which rested on the lack of knowledge of its own destructive effects. The same analysis could be extended in contemporary times to show that underdevelopment is a direct consequence of the development of Western societies (D'Onofrio 2018, 51). In the prologue of Saudades do Brasil, Lévi-Strauss emphasized that the said primitives are not only the victims, but also the mirror of the West. We are arrived at a stage where the excesses of the capitalist mode of production in terms of social inequalities and ecological dangers must make the Westerners recognize they share the precariousness of the primitives, who are actually "regressive," and that "we are all Indians now," "survivors of a catastrophe in progress" (Lévi-Strauss 1994).

His reflections were utterly inaudible at the time, but the coming ecological catastrophe forces us to recognize his extraordinary prescience. His prophetic and apocalyptic tone, which will become even stronger in the 1990s with the Italian chronicles on the mad cow crisis (Lévi-Strauss 2013, 217-230 [Eng.112-119]), must not, however, lead to having a series of disasters one after another, as if the disappearance of the Indians, the extermination of Jews and the destruction of livestock were accounted for the same. In Lévi-Strauss's work we find the elements of an "anthropo-ecological manifesto" (D'Onofrio 2018, 100), which can show the emergence of structural anthropology as a diagnosis of the wrongs of Western civilization and a urge to set them rights by proposing a response to catastrophic excesses. The "lessons in wisdom" that Lévi-Strauss found in Amazonian 
societies consisted in describing the conditions of emergence of social life in a disaster situation in order to shift their meanings to other similar situations.

Native American societies offered exemplary cases of openness to otherness, allowing them to mitigate the impact of unpredictable events. If they offer "models" for thinking about the ecological catastrophe, "the unpredictability of history opens the possibility of anti-catastrophic creativity, that is, a reconstructive creativity that can be manifested within the crisis situations that industrial societies in the West produce structurally" (D'Onofrio 2018, 92). Creativity is here the ability of human societies to rebuild subjectively after the encounter with societies that have profoundly altered their structure. Here one realizes all the weight of Lévi-Strauss's musings on Japan and his manifest concern of a paradigmatic stability. In the course of excessive industrialization and urban planning, he highlighted the possibility of a choice between two qualified and alternative extremes, rather than a decision exclusive of any other that could be made.

\section{A system of invariant differences}

A recurring theme in Lévi-Strauss's posthumous collections, more or less well substantiated, is to find in realms as varied as spoken language, artisanal techniques, culinary preparation, and the history of ideas "a system of invariant differences" between Western philosophy and other ways of metaphysical thinking. In his writings on Japan, it reveals itself between what he called "the Western soul and the Japanese soul, which can be summed up by the opposition between a centrifugal and a centripetal movement" (LéviStrauss 2011a, 39 [Eng.25], 2011b:51 [Eng.37]).

At a superficial level, Lévi-Strauss may seem engaged in exactly the same enterprise of cataloguing the sundry ways in which Japanese practices are the diametrical opposite of European ways (Launay 2013,43), which may come awfully close to the worst of earlier, notorious topsy-turvy reports of European travelers on Japanese culture (Hayot 2013). However, because Japan has so often played the role of a backward world in the European imagination, Lévi-Strauss's reflections on similarities and differences encourage us to view people of cultures different from our own as equals who bear striking similarities to ourselves. To understand the incomprehensible means of the recurrent and arrogant West European opinions, Lévi-Strauss's insight is to "domesticate strangeness" thanks to a certain approach respectful of otherness and a resourceful advocacy for the recognition of a symmetry between two cultures, which unites them by placing them in opposition. "They appear both similar and different, the symmetrical image of ourselves reflected in a mirror, an image irreducible to us, 
even though we find ourselves in every detail". Indeed, "when the traveler convinces himself that practices in complete opposition to his own, which by that very fact he would be tempted to despise and reject with disgust, are in reality identical to them when viewed in reverse, he provides himself with the means to domesticate strangeness, to make it familiar to himself" (Lévi-Strauss 2011b, 131 [Eng.112]).

If the Japanese do many things in the reverse of Europeans and vice versa, by an exercise of practical anthropology, Lévi-Strauss showed how Japanese culture illustrates the construction of identity "from outside" as the result of a movement that returns from the other to oneself. At the opposite of the movement in Western philosophy since Descartes where everything starts from the self, "Japanese thinking makes the subject a result rather than a cause" (LéviStrauss 2011b, 51 [Eng.37]). This is what the founder of the Kyoto School of philosophy once called the "logic of the predicate" and contrasted with the Aristotelian "logic of the subject" (Ohnuki-Tierney 2014, 434). Rediscovering the dual refusal of the subject and the discourse, Lévi-Strauss showed how the Japanese protect themselves "from the metaphysical renunciation of the Eastern religions, from the static sociology of Confucianism, and from the atomism to which the primacy of the self makes Western societies vulnerable" (Lévi-Strauss 2011b, 52 [Eng.38-39]).

Lévi-Strauss's reflections reveal that different cultures show alternative ways of performing the same vital functions, and that different people choose different strategies in overcoming the existential and social problems of human life. He makes sure to clarify that the fascination Japan exerts both in Europe and the United States is not simply because it followed their technological progress and economic success. More importantly, in his eyes, Japan is the only society which was able to do so by overcoming Western contradictions and elaborating its "own formulas for living and thinking” (Lévi-Strauss 2011a, 143 [Eng.122]), where the hypermodernity of technology revivifies instead of destroying traditions. Japan is astonishing with its capacity to alternate between two modes of conduct and share its allegiance between native deities and "invited gods" (LéviStrauss 2011a, 144 [Eng.123]). Rephrasing his observations expressed in Tristes Tropiques, Lévi-Strauss found in the Japanese exception "an original solution to the major problem of our time," stating that it is possible for a society to change without substituting one culture for another. "Japan, perhaps alone among nations, has until now been able to find a balance between fidelity to the past and the transformations brought about by science and technology" (Lévi-Strauss 2011b, 155 [Eng.135]). Beyond the dualisms, Lévi-Strauss insisted on the unique balance achieved by Japanese society to provide ways of coexistence of opposites in the juste milieu between past and present, myth and history, tradition and modernity, 
science and belief, nature and culture, refinement and brutality, East and West.

Both technologically advanced and still close to its founding myths, Japan seems to invent a "unique way of posing the problems of modern humankind and by the solutions it offers, it can teach anthropology a great deal" (Lévi-Strauss 2011a, 146 [Eng.125]), according to a formulation that can be applied to the master himself and more broadly to his anthropology. As Edmund Leach once reminded, Lévi-Strauss's importance lies in the mode of discourse he invented to display facts and frame explanations and ideas, suggesting new and unfamiliar ways of looking at familiar facts, and thereby provoking thought about fundamentals (Leach 1970). The occasional papers collected in these volumes remind us the astonishing chapter on "totem and caste," where Lévi-Strauss sets out to demonstrate that the structure of the Indian caste system is a logical transformation of the structure of the totemic order of Australian Aborigines (Lévi-Strauss 1962, 144-177 [Eng.109-133]). In Leach's terms, "intellectual firework" of this kind do not in themselves enlarge our understanding of either the caste order or Australian totemism, but they do challenge us to think more deeply about human society and about what is specifically human (Leach 1964, 111). As it seems, sometimes what one learns by doing structural anthropology is more important than the positive knowledge that structural analysis might actually establish. Or, as Lévi-Strauss himself once famously put it, "the proof of the analysis is in the synthesis" (Lévi-Strauss 1960, 161).

Most anthropologists would find today hard to agree with Lévi-Strauss's argument of the contrast between "Western-type" and "primitive" civilizations. For some, his fascination with "primitive" societies in general, and with the East or with Japan in particular, seems skewed and out of date. His conservative view that anthropologists "wish to let things be" becomes even more problematic when they "want all individuals to submit to the internal logic of their own societies" (Lévi-Strauss 2011a, 75 [Eng.59]), as if the logic of many societies were not deeply troubled (Cerni 2013). Indeed, Lévi-Strauss often appeared to have a nostalgic or romantic attachment to "primitive" cultures, which he considered more authentic and more able to "establish a balance between humankind and the natural environment" (Lévi-Strauss 2011a, 52 [Eng.38]). While admitting they are parochial, he nevertheless admired the fact that "societies of a very low technical and economic level may possess a sense of well-being and plenitude as each one believes it is offering its members the only life worth living" (LéviStrauss 2011a, 88 [Eng.71]). For others, this "vision of primitive societies seems much prettified" (Godelier 2013, 474 [Eng.443]), while Lévi-Strauss's assertion that non European societies have already identified solutions to 
contemporary problems seems a message of "old-fashioned cultural relativism" (Launay 2013, 42). A more important difficulty for this view of anthropology is that primitive societies are not what they were, or might once have been, and Tristes Tropiques was already an elegy to their vanishing (Kuper 2013). The very process of colonialism that revealed them to European scholars, and made them accessible, almost immediately began to erode their independence and their integrity.

Some of Lévi-Strauss's observations on many practices may be too favorable toward Japanese culture and society. At times, they are surprising or outdated. Often the diversity that he held so dear may also seem to remain purely abstract, a diversity of forms and manifestations dissociated from social and historical context. Actually, some invariant differences may be the product of a recent history and do not reflect an archaic mentality. We may nevertheless maintain these moments of uncertainty, at least because the Western knowledge of Japan shows a deadlock of history that anthropology is shaking up. Against the criticism of his ahistorical approach, Lévi-Strauss elaborated on his own views about the "irreducible contingency" of history, namely "going beyond the apparent diversity of human societies" in order to provide a great anthropological theory of the nature of history, claiming to reach back to common and fundamental properties and structures, which are only validated by "submitting to the powerful inanity of events" (Lévi-Strauss 1966, 408 [Eng.475]). While he was aware of the vast difficulties and unprecedented intellectual challenges of cross-cultural comparisons (Lévi-Strauss 1991), in his view, the primary representation of the anthropological object combines objective ethnographic observation, a "view from afar," with unrestricted comparison, aiming at generalizations about human social life.

In his Japanese musings, confronted with history, he managed to overcome it by the logic of symmetric histories and mythologies, both similar and opposite. Indeed, he was interested in Japanese culture and the vagaries of Western modern life only because he perceived the echoes of hidden anthropological logics that work out a broader, almost cosmogonic, understanding of the present. The significant reversals and the strange mixture of roles that Japan has played in world history allowed him to take a longue durée in his interpretation of Japanese history as a sort of limit-case for modernity in global context (Lévi-Strauss 2011b, 31 [Eng.18]). He vigorously provided a clear justification for structural analysis in undertaking comparisons that avoid confusing explanations based either on historical diffusion or on independent origin. The occasional Japanese papers are not detailed enough to do justice to the comparative approach between American, European and Japanese mythologies. Still, they are most 
compelling in his discussion of Japan as a kind of civilizational alembic between Europe and the Americas across the indigenous populations of the Pacific Rim, and hence of great significance for the comparative study of myths and their resonance with certain themes in the Japanese, South American and European folk-tales.

$\mathrm{He}$ also re-elaborated and clarified the demonstrated usefulness of his famous distinction between "hot societies" conducive to change and "cold societies" hostile to change, to affirm the conclusions exposing Western arrogance about the "peoples without history." If people explain the world to themselves through myths, these are conservative and impose order on society and nature, crucially by maintaining the illusion that things do not change, and indeed helping to maintain social equilibrium and long-term stability. Yet, in his thermal analysis of history, "historical knowledge preserves affinities with myths," concluding that cold societies escape the ethnocentric conception of history in modern societies, which offers in turn a mythology of necessary change. Actually, each modern political tendency is rooted in its particular historical myth that links an imagined past to a longed-for future (Kuper 2013). History ends up "occupying a role comparable to that of myths," including the invention of historical change and progress that "expresses not so much objective truths as prejudices and aspirations" (Lévi-Strauss 2011a, 102 [Eng.85]).

All this to refuse, with a brilliant prophecy in his days, the domination of a single norm in human affairs that "reduce all types of social development to a single model" (Lévi-Strauss 2013, 77 [Eng.35]). Which allowed his impassioned defense of cultural relativism, as he diligently attacked evolutionism, race-based cultural discrimination, the evils of colonialism, or the hubris of Western modernism and ethnocentrism, constantly asking provocative and prescient questions. In his return to Montaigne in 1992, Lévi-Strauss identified three different ways of defining savagery or barbarism, not always clearly stated but sufficiently recognizable, which indicate the ways of thinking that anthropology will later follow (Lévi-Strauss 2016a, 80-83). Whereas thinking about the savage as close to natural laws and not yet adulterated by the laws of society lead to the theory of the noble savage, another orientation of Montaigne's thought toward building a rational society lead to the theory of the social contract. Yet, another direction at odds with the previous ones, namely no society can be said to be barbarous on the grounds of reason because all customs have a function and a raison d'être, lead to integral cultural relativism.

In Lévi-Strauss's eyes, the doctrines of contemporary anthropology are clearly found in the different ways of Montaigne's thought that opened two 
opposite perspectives to philosophical thought. On the one hand, the philosophy of the Enlightenment, out of which anthropology grew, subjected all historical societies to its criticism and devised the rules of the cherished utopian dream of a rational society of the sort that all societies should wish to become. On the other hand, "relativism rejects any absolute criterion by which a culture could allow itself to judge different cultures" (Lévi-Strauss 2013, 149 [Eng.74-75]). Even today, philosophers do not seem to have found a way out of this contradiction. In turn, Lévi-Strauss was able to highlight a hidden tendency of many anthropologists, who today are often guilty of reinforcing colonialism through a fetishized fascination with the indigenous subject (Foster 2017). He reminded us that the ethnocentric point of view serves to construct a world in which the meaning of what we are doing is hidden in plain sight, albeit it is refracted through the figure of the savage other that we hold up as an index of our own progress (McLennan 2016).

Taken together, these volumes recapitulate Lévi-Strauss's longstanding project of dismantling the models of progressive evolutionary history that conferred on the West the sense of its own exclusivity and originality. The underlying theme of his lifelong endeavor is to challenge the great divide between the West and the Rest, placing the other as equal to the EuroAmerican self. In unexpected themes, he gives us food for thought about our present lives, reflecting us a mirror image of societies that we mistake for primitive or archaic. Facing both current affairs and the role of history in modern societies, he relentlessly put into question the idea of progress and the ethnocentric vision of Western societies where human beings live under a kind of internal poisoning regime, which we naively qualify for modern.

Lévi-Strauss also endeavored to imagine a globalized human culture that does not borrow its social, philosophical and emotional logics from the deprecated Western experiment. He insisted on the need to "look elsewhere" and "widen traditional frameworks" of Western thought by focusing anthropological analyzes to small-sized groups of population and to the role of myths and mythical thought in these "most humble societies, long held in contempt" (Lévi-Strauss 2011a, 49 [Eng.36]). He argued that the other's wisdom points to the end of Western cultural supremacy, as "Western-style civilization has lost sight of the model it had set up for itself and is no longer bold enough to offer that model to others" (Lévi-Strauss 2011a, 16 [Eng.4]). Lévi-Strauss revealed himself both disillusioned and dispassionate, elegantly situated between a tonic pessimism and a vertiginous lucidity, which are jointly exposed in his characteristically personal style as both the figure and the ground, the cause and the symptom, of his anthropological analysis of the human condition. 


\section{Social ontology and biopolitics}

Confronting our anxieties with the customs of others, Lévi-Strauss entered into difficult thickets of thought to trace the lineage of contemporary controversies over the body and society, which provide highly useful insights to scholars of contemporary biopolitics (Foster 2017). Indeed, he wrote the most vivid pages that highlight the ever-present connection between the biological and the political with contemporary media events and societal facts.

His 1952 essay provided a subtle analysis that remains an exemplary model of an anthropology of media events, seizing the controversy that hit French headlines on the Christmas Eve of 1951, when a Santa Claus effigy was hanged and burned publicly on the parvis of Dijon cathedral before children of Catholic schools (Lévi-Strauss 2016b). He confronted the advocates of the traditional Christmas celebrations, those who denounced a "worrying paganization" of Nativity and those who were adopting a "pagan" personage able of filling the void left by de-Christianization in modern society. Santa Claus was criticized for his alleged heresy and his deceitful character, "which turned thoughts away from the properly Christian meaning of the celebration in favor of a myth without religious value" (Lévi-Strauss 2013, 15 [Eng.1]). Moreover, both sides raised against all publicity of a symbol of Americanization that would have definitively marked the passage from the Father Christmas as a mediator between the generations to that of a simple instrument of marketing to the service of consumer society.

In a simple language free of any structuralist jargon, Lévi-Strauss showed the fundamental melancholy of this pagan celebration renounced by the Church in France in the 1950s, and while the whole essay remains relevant, even or especially in a neo-liberal context, it is exemplary of the all-encompassing and irresistible power of the structural analysis. In this wonderful piece of his writings, Lévi-Strauss linked Father Christmas to "very old elements" of ancient usages back to Roman Saturnalias, celebrations of the dead, Halloween, and initiation rites, all revivified in striking patterns by the analysis of tales, legends and myths that are at the basis of rituals. The common thread is the motif of the symbolic function of mythic and ritual structures that constitute an underlying system within social ontology.

For Lévi-Strauss, the Christmas incident illustrated the functions of society along "a dual rhythm of increased solidarity and exacerbated antagonism presented as a pair of correlative oppositions" (Lévi-Strauss 2013, 38 [Eng.14]). He sought to explain not "why children are fond of Santa Claus but rather why adults were impelled to invent him." As "Christmas Eve dinner is by its very nature a meal offered to the dead, where the guests play the role of the dead, children that of angels, and angels themselves 
that of the dead," he argued that "it is therefore no surprise that Christmas and New Year are gift-giving holidays" (Lévi-Strauss 2013, 43-44 [Eng.17]). Giving the "dead" children treats was a stage of their acceptance coming back from the dead. In this sense, the story of Santa Claus ought to be understood, within the broader context of a sociology of initiation, as a means of expressing the differential status between children and adults. As "it is quite certain that rites and myths of initiation have a practical function in human societies to help elders keep youngsters well-behaved and obedient" (Lévi-Strauss 2013, 30 [Eng.10]), Santa Claus and Christmas gifts are indices of a stage of children acceptance as full members of social ontology.

On these issues as on others, on the historicity of generations and the origin of society, the prohibition of incest and sexuality, or the foundations of human thinking, Lévi-Strauss never departed from his acute sense of analysis. Occasionally, he was even outraged by the lack of rigor of some of his colleagues, sometimes administering them a fraternal or a sarcastic correction, as in the case of naive attempts to assign simplistic biological groundings to complicated intellectual activities, which he treated as "genital Robinson Crusoe tales" (Lévi-Strauss 2013, 211 [Eng.109]). In his essay on female sexuality and the origin of society, Lévi-Strauss did not take direct issue with any of them, but he had clearly in mind Godelier's stubborn supposition that the loss of estrus in human females led to a generalized form of "cerebralized" sexuality, requiring humans to invent kinship as a system for artificially regulating and organizing the reproduction of society (obtusely rehearsed again in Godelier 2013, 240-241 [Eng.209210]). Lévi-Strauss suggested to anyone who would let themselves be tempted by the little estrus game of quell'intenso profumo di donne, that, all in all, the least absurd hypothesis would be to place the loss of estrus in a direct relationship with the appearance of conceptual thought and articulate language, simply because culture shapes nature and biology, not vice-versa: "In terms of understanding human evolution, the really interesting things occurred in the brain, not the uterus" (Lévi-Strauss 2013, 214 [Eng.111]).

Likewise, Lévi-Strauss refused to take a stand on whether genital mutilation always constitutes a harm. Albeit on the strength of anecdotal evidence and the dubious grounds that "opinions differ," he subtly ironized that "our knowledge of the vicarious role of the erogenous zones is so imprecise that we would do better to admit that we know nothing about it" (LéviStrauss 2013, 86-87 [Eng.40]). He even insisted that the role of the anthropologists, called upon to shed light on the practice in immigrant communities, is simply to demonstrate its coherence within the cultural systems in which it takes place. Surely, "it is both false and pernicious to treat immigrant communities as monolithic in this respect," and 
Lévi-Strauss who "insisted upon underlying cultural grammars risks reifying the culture of the immigrant community, giving a false impression of unity and coherence" where there is actually tension and conflict. In particular, his invocation of a monolithic "they-who-hold-their-rights" is particularly troubling, considering that the rights of the girl or the boy submitted to genital mutilation are apparently not even at issue. However, despite the appearance of "old-fashioned cultural relativism" and "the very banality of such observations" (Launay 2013, 42), the stance expressed here is not "maddeningly relativistic," neither "enlightened conservatism" (McLennan 2016). Lévi-Strauss's alleged equivocation does not highlight the poverty of his sociological imagination, precisely because he is offering a bulwark against anti-immigrant racism.

He considered both practices of female excision and male circumcision on the same plane as two equal genital mutilations. Male circumcision constitutes "an assault of the same kind," but it is less disturbing "because our Judeo-Christian culture is still steeped in the Old Testament and that such familiarity removes any shocking aspect male circumcision might have" (Lévi-Strauss 2013, 86-87 [Eng.40]). Even though in his eyes, "there are no grounds for punishing, in the name of a particular moral code, people who are simply following practices dictated by a different code," in his conclusion it is not self-evident that we must nevertheless tolerate such cultural practices even once we have understood them. His rejection of female excision is not based on condemnation from a superior truth, but rather in the simple name of "an ethical choice that engages the future of the host country's culture” (Lévi-Strauss 2013, 90 [Eng.42]). He offered no concrete advice on how it might be decided simply because the burden of choice would fall on society rather than the anthropologist.

Lévi-Strauss is equally dispassionate regarding assisted reproduction and homosexuality, or those moody states of mind that are panicked by the legal puzzles that may result in newer forms of kinship and family from same-sex marriages, surrogate mothers, or posthumous children born of frozen sperm. Nonetheless, even more than thirty and even fifty years after the fact, his Elementary Structures of Kinship (Lévi-Strauss 1967 [1949]) is often and commonly criticized in order to justify social and political mobilizations of the moment. In the 1970s, because of a supposed differential valorization between women and men, the feminists regarded it as a treatise of sexism (Rubin 1975). In the late 1990s, it became homophobic because of another differential valorization between heterosexual marriage and other forms of alliance (Fassin 1999). With the movements for homosexual rights to marital union and parenthood, it suddenly became a reference in the political debates regarding the new technologies of procreation and the regulation of biotechnologies, wielded at once for and against the 
Bible as another founding text. Remarkably, it also leads to radically opposite conclusions, depending on whether one wanted to promote or reject homosexual rights. If opposite partisanships may have found their source of inspiration in his work, Lévi-Strauss was not responsible for the legal designs in which experts and legislators found themselves engaged. After all, there is no relationship between the political instrumentalization of Lévi-Strauss's theory and the knowledge that Lévi-Strauss tried to build throughout his work (Favret-Saada 2000). In other words, the political normative implications of Lévi-Strauss's conceptualization of the symbolic order are beyond question, but there is no need to suppose a new "structuralist social contract" (Robcis 2013) to preserve heterosexual exchange or allow same-sex marriage.

While there is no need to reaffirm the political dimension of LéviStrauss's work, which might have been criticized from start but never questioned, this reinvigorates the analysis of his oeuvre in ways that turn the focus away from what is deemed the intellectual sterility of his work on symbolism, and toward his profoundly politically project (Asch 2005). This perspective effectively counters the narrow-minded analyses of the feminist critique (e.g. Butler 2004), which truncately focus on his supposed misogynist objectification of women, his alleged homophobic valorization of heterosexual marriage against other forms of alliance, or his claimed essentialist reproduction of transmissible racial purity (Strong 2002). Lévi-Strauss's theory provided conceptual tools to perceive, analyze and name the logics of how gender is a socially imposed division of the sexes, a product of the social relations of sexuality that transform males and females into social beings. What Lévi-Strauss called "exchange of women" is a seductive and powerful concept that placed from the start the oppression of women within social systems rather than in biology, while his view of the origins of society in the incest taboo leads to a fundamentally anti-liberal understanding of the inescapability of social relationships.

Not surprisingly, Lévi-Strauss distanced himself from the political normative instrumentalization of his work, and as always, he put face to face the partisanships from any camp. He could only remind that the range of human cultures is so large, so varied, and so easily manipulable, that we find without much trouble arguments supporting whichever thesis. In turn, the familiarity acquired with the most various customs teaches the anthropologist, at best, a certain wisdom, which cannot be useless to their contemporaries. We must not forget, however, that "the choices of society do not belong to the scholar, but to the citizen" (Lévi-Strauss in Fassin 1999, 110). The access of same-sex couples to marriage and descent comes within the responsibility of a political choice, not with any scientific necessity. 
The role of the anthropologist is to distinguish and describe the determinant conditions under which certain conceivable solutions to the problems of life in society have proved to be viable. However, citizens in search of new choices of society will not learn anything by the study of all possibilities implemented by various human groups; nothing, if not a modest wisdom before making any political choice of society.

Already in his Japanese lectures given in the 1980s and in his Italian chronicles of the early 1990s, he provided ethnographic examples to show how various cultures have long been able to offer solutions to analogous problems of childbirth, kinship, and filiation without collapsing. These societies know nothing of the modern techniques of in vitro fertilization, the removal, implantation, or freezing of eggs or embryos, but they have imagined and put into practice what are equivalent options at a metaphoric and symbolic level (Lévi-Strauss 2011a, 69 [Eng.53]; 2013, 94 [Eng.44]). Since they believe in the reality of these metaphors, the psychological and legal implications are the same to permit forms of same-sex marriage or judge normal the gift of children and the reincarnation of ancestors.

This is gratifying reading and unexpected enlightening, since both the conservative right and the radical left are bulling into warnings of civilizational disintegration or claims of societal emancipation because of the co-existence of nontraditional kinship forms with the patriarchal nuclear family. He asked presciently whether all this should be allowed. Long before the stormy public debates between "marriage for all" and "demo for all" that agitated Western societies and their National Parliaments since the 1990s, and even before some anthropologist's path-breaking work that took over the worldwide implications of the medical developments behind these debates, but treated Lévi-Strauss rather condescendingly (Strathern 1992). Yet again, Lévi-Strauss's conclusion is very clear, for "the anthropologist does not propose that his contemporaries adopt the ideas and customs of one or another exotic population" (Lévi-Strauss 2011a, 73 [Eng.57]). Probably the only teaching that may help us rid ourselves of our own blinders is that these societies unhesitatingly give primacy to the social, without the conflict we find so troubling between biological reproduction and social paternity could clash in the ideology of the group or in the minds of individuals. In this area, Lévi-Strauss's argument is only intended to illustrate the historically contingent nature of our choices, as our moral judgment cannot claim to be universal but only a political decision that engages a community of citizens.

Implicit in the claim that "we are all cannibals" is again a definition that extends beyond common representations and conceptions of cannibalism. Against those who are horrified by cannibalism, Lévi-Strauss showed how cannibalism is not something that humanity has moved beyond, but rather 
something that continues to be a part of society. In the intersections of society and biology, what he called a "therapeutic cannibalism" includes medical procedures like blood transfusions, organ transplants, or hormone injections extracted from human brain membranes. This is not surprising, as he is writing at the time of the moral panic surrounding CreutzfeldJakob disease. Three years later, he found a confirmation of his observations in the outbreak of the disease from the same family, known as mad cow disease, which was transmitted through animal flours of bovine origin fed to livestock, therefore resulting in "the transformation of cows into cannibals by human beings" (Lévi-Strauss 2013, 220 [Eng.114]). These chapters form a genealogy of these contemporary panics and provoke the reader to question the conditions that have led to cannibalism in the past and the reasons that have led to the stigma surrounding it.

In October 2015, I assigned the students of my methods class at the University of Lille to ethnographic observation of an immediate appearance session at the High Court of Lille, after which they had to think anthropologically about the role of justice, in particular about the behavior of our society to discipline and punish. Our judicial and penitentiary customs consist in expelling certain forbidding beings from the body public by isolating them for a time or forever, denying them all contact with humanity, in establishments devised for that express purpose. According to Lévi-Strauss, in most of the societies that we would call primitive, these customs would inspire the profoundest horror and would mark us in their eyes with the same barbarism that we would be tempted to impute to them on the ground of their no-more-thansymmetrical customs. Already in the Tristes Tropiques, he found it tempting to consider our judicial and penitentiary customs in relation to the societies that practice cannibalism. That is to say, societies who believe that "the only way to neutralize people who are the repositories of certain redoubtable powers, and even to turn them to one's own advantage, is to absorb them into one's own body" (Lévi-Strauss 1955, 464 [Eng.386]).

Cannibalism "in itself has no objective reality, but it is an ethnocentric category that exists only in the eyes of the societies that proscribe it" (LéviStrauss 2013, 172 [Eng.88]). If barbarism is a matter of cultural relativism, it is grotesque to believe that we have made a great spiritual advance simply because we refuse to "ingest," that is to say, reinsert and reintegrate some of our forbidding fellow human beings into the body public. During their ethnographic observation of the immediate appearances at the High Court of Lille in October 2015, my students constantly witnessed the infantilization of the defendants. The judge systematically displayed a notorious arrogance in addressing them and the prosecutor diligently requested exorbitant penalties for offenses committed, while the defendants' explanations only increased the contempt that the judicial institution 
showed them that day. Indeed, as Lévi-Strauss had warned, we are no less to blame for the manner in which "we prefer to mutilate them, both physically and morally" (Lévi-Strauss 1955, 465 [Eng.387]). There is not a large gap between so-called primitive and so-believed modern societies, and as always, Lévi-Strauss warned those who attribute revolting customs to others for only to confirm the belief in their own superiority.

\section{Structural legacy and the future of heroic anthropology}

A sense of anthropological purpose lies behind and informs the rapid growth of mesmerizing analogies between different histories, social practices, and mythologies in these writings. With the hindsight and the height of his work and position in the academic and intellectual realm, by giving accounts of structure and history, prescient here as elsewhere, Lévi-Strauss "invited us to celebrate the architecture of mind, empowering facts not only for the pleasure of thinking" (Kristeva 2016), but also for thinking about social transformations. As usual, he provided intuitions, probing shots, lighting projections that allow to better grasp the singularity of the other and the self. We are "stimulated by Lévi-Strauss's attempt to have us see one another each through the other's eyes," (Strathern 2018) and we might be moved in turn to contemplate how much our common mental structures bring us closer to peoples, whom we tend to see as radically different.

He confessed that his View from Afar was inspired by the Japanese master Zeami's Noh actor, who "to judge his performance must learn to see himself as if he were the spectator" (Lévi-Strauss 2011a, 44 [Eng.31]). LéviStrauss turned his view from afar to the Amazon, to Japan, and to the contemporary problems of our society not only to scrutinize cultural differences, but also to subsume relations between civilizations and distance himself critically from the deleterious effects of Western ideologies and technologies. The early writings, the musings on Japan and the Italian chronicles are probably the place where Lévi-Strauss carried this concept of a view from afar to its utmost. Rather than a physical distance, he apprehended the universal character of patterns that trace the curvature of space and time.

For a period, Lévi-Strauss's structural analysis had a powerful influence on both British and American anthropologists, offering a way out of functionalism and empiricism (cf. Doja 2005, 2006c). Although his reception in the Anglo-Saxon world was always mixed (Geertz 1967; Leach 1970), there was also support and admiration for Lévi-Strauss even late in life (Wiseman 2009). More importantly, he had remained a source of fascination and inspiration for the younger generations of North and South American knowledge-based anthropologists. Over the years, the coming 
back of structural method as "the only way out of the postmodernist perplexing difficulties" has been heard from younger colleagues in international anthropological meetings. ${ }^{6}$

Following the poststructuralist imposture (Doja 2006a), the upheaval that Western academia experienced from the 1980s onwards has been subtle, but dangerous, and has resulted in a specific minority of rabidly ideological academics, who have tried to stifle debate and oppose scientific knowledge, including Lévi-Strauss's legacy. As a result, there seems to exist a total misrepresentation and misrecognition of Lévi-Strauss's standing, especially in contemporary North American anthropology, where he seems to be on the verge of total irrelevance as a few cultural anthropologists see themselves as at all influenced by his approach while postmodern anthropologists reject it outright.

Lévi-Strauss may be read in the context of the history of anthropology, but he is usually dismissed, ironically for the very reason he must be praised, namely his insistence on scientific rigor, simply because this concept has become somewhat alien to postmodern anthropologists. The result of this situation is less a steady critique of Lévi-Strauss than a particularly insouciant neglect. To put it bluntly, in the United States or Britain today, frequently graduate students of anthropology do not read Lévi-Strauss who is even hardly mentioned in graduate courses, which is tragically shortsighted for the discipline. What seems most dramatically critical is that most American anthropologists do not even think Lévi-Strauss is important enough to be argued with. Indeed some anthropologists may still perceive him as out of date and unfashionable. He is simply ignored in the day-today practice of a discipline that had long embraced post-modernism. For some, he is just another "dead white man", as I found when I offered to teach a course on him at Harvard in 2017-2018. ${ }^{7}$ As if people's Caste of Merit were not to be credited by how they are "good for thinking," but by the color of their skin, their gender and sexual orientation, and by the postmodern Shorelines of decolonized indigenism, subalternism, and racialism they should originate from.

One look at the new generation of postmodern anthropologists would be enough to fathom that none of them even bothered to read Lévi-Strauss's scholarship, which would indeed be civil and intellectual. Simply speaking, almost none of them will be qualified to judge any subject Lévi-Strauss dealt with, but almost all of them can be described as lit. crit. activists situated somewhere between bad arrivisme and ugly kitsch. Postmodern professors are teaching students that there is no truth, that science and empirical facts are tools of oppression by the white patriarchy, and that nearly everyone among their own progressive professors is racist and bigoted, including Lévi-Strauss. 
In a time of global crisis, the task of thinking broadly about the human condition has become extremely difficult after post-structuralism and deconstructionism had produced a generalized suspicion of totalizing statements and grand narratives. As most anthropology and scholarship is becoming highly particularistic, Lévi-Strauss's reassertion of the universalistic perspective is a useful counterpoint (Harkin 2019, 88). Over the last years of his life, Lévi-Strauss was often described as apolitical, sometimes even characterized as reactionary, and he was certainly not an activist. However, throughout his life and in his work, he devoted himself to fighting the social ills of racism, the destructive effects of colonial expansion, the great massacre of cultures, the extermination of populations, and the ecological disasters of environmental destruction. Whereas the lack of political concern of an entire generation of his predecessors spared them from confronting the question of what role anthropological research must take in the face of the colossal phenomenon of Western colonialism, it is precisely this question that was at the center of Lévi-Strauss's work, long before the postcolonial, postmodern, poststructuralist, and deconstructionist critical turns in social sciences and the humanities. Later in life, he rebelled again with an unprecedented virulence against those politically correct postmodernist approaches that "overcloud the moral faculty of a feeling of revolt in front of the crime committed by the West" against Native American cultures (Lévi-Strauss 2001a, 441).

Not only the epistemological issues of anthropological knowledge, but also the ethical conception of the anthropologist's work is consistently present throughout Lévi-Strauss's work, in its ontological, etiological, and salvational dimensions. In his view, anthropology was a lone heroic quest against blindness and blandness, in which the anthropologist aptly could be hailed as "a hero of our time" (Hayes and Hayes 1970; Sontag 1963). Actually, Lévi-Strauss dealt with both the nature and the denaturation of humanity and society, trying to return to the means, or showing the absence of means, to alleviate these evils.

Clearly, it is his own adroitness and talent to have been able to establish the theoretical foundations of a revolutionary contribution, both scientific and humanistic, to general anthropology. In my opinion this contribution is also far-reaching and represents the most compelling challenge to the future of anthropology in the 21st century (Doja 2008a, 2010a). Contrary to the received ideas of his critics, little of recent topical, ethical, methodological, or epistemological interest escaped Lévi-Strauss's notice, understanding, and engagement. His corpus of work is comprehensive in scope, encompassing methodology, philosophy, history, humanism, mythology, linguistics, esthetics, cognition, and reasoning. Lévi-Strauss's ambition was to provide a new epistemology and a new ethics, involving a set of novel 
assumptions and procedures for the acquisition of knowledge, a new approach to methodology, and a new global awareness.

Lévi-Strauss was a visionary genius who perceived large patterns of oppositions and symmetries in the world, trying out various inversions and other structural operations to discover what is and is not subject to permutation. His preoccupations might seem to be very abstract, but in his challenge to think about the vast array of social specificities together, he remained open to the contradictory possibilities of originality and commonness (Hayot 2013). Indeed, Lévi-Strauss was basing many of his structural claims on extremely detailed and concrete features, such as the social relations between Amazonian war and trade or the accustomed direction of movement in Japanese sawing and sewing toward rather than away from an actor. He weaves a mesmerizing set of patterns and transformations, constructing a system of invariant differences between France and Japan, or the West and the Rest at the opposite ends of the Eurasian and American continents. At points, they have the effect of suggesting that human reality is always an emergent realization of the massively constructed, but logically possible, inversions along a multiplicity of these concrete dimensions. The perspectives so framed and manipulated produce occasionally startling coincidences that demonstrate the astuteness of employing the structural method.

Much understanding of the structural method comes from Lévi-Strauss's early manifesto-like pronouncements and the reinterpretations or misinterpretations offered by poststructuralists, notoriously Derrida and his imposturous critique of Lévi-Strauss on the place of writing (Doja 2006a, 2007), or Foucault who proclaimed the death of the human subject. Recently, several scholars have argued that structuralism as it is popularly imagined is a retrospective invention by poststructuralists which has come to be substituted for the real thing (Doja 2006b, 2008a; Henaff 2011; Wiseman 2009). Such caricatured reconceptualizations of structure and structuralism cannot and should not obscure Lévi-Strauss's more decisive notions of differential imbalance and transformation.

For a long time, a major criticism to Lévi-Strauss's structural analysis has been the definition of the place of events and human agency in the reproduction of systems and the transformation of their structures over time, and a colossal work is needed to take the challenge of extending and reorienting Lévi-Strauss's pathway. Anthropology today concerns itself with questions of identity politics, migration, diseases, famine, poverty, feminism, reflexivity, corruption, illiberalism, globalism, ethnic conflicts, civil wars, human rights, cultural activism, fundamentalism, terrorism, and many other related themes. An attempt to restore Lévi-Strauss to a central 
position can hardly prove immediately relevant to all of these social and political issues.

Yet these posthumous publications reveal the trinity of myth, history, and objective knowledge in different proportions in every society (Kuper 2013), or they complement the current interest in the intersections of biology and politics, aptly bringing an important contribution to the study of biopolitics (Foster 2017). Lévi-Strauss's algebraic tendencies may also be thought as an important resource for considering anew the resistance to ideology in the present time (McLennan 2016). It is indeed possible to show that structural anthropology may innovatively account both for the dynamic process of praxis by which social relations and social systems are enacted and transformed and for the competitive and strategic practices of social behavior. It may well be that returning to Lévi-Strauss will give us the courage to attempt syncretism once again. In particular, if we can enlarge structural thinking to include hidden ideology and instrumental politics, a convincing argument can be offered to reveal the continued relevance and usefulness of Lévi-Strauss's work for contemporary social scientists and theorists.

Some of Lévi-Strauss's achievements could lay strong claim to having mapped, within anthropology, the philosophical parameters of an increasing preoccupation with issues of contextualization and reflexivity in the face of the declining coherence of meta-narrative and grand theory, as well as with issues of political concern and engagement in the post-colonial era (Doja 2006b). We may be correct in asserting that Lévi-Strauss used structural arguments coherently and correctly to analyze the cultural order and its transient character by means of entropy and irreversibility, as well as, unsurprisingly, to examine deconstruction, or rather "dissolution" (in his own word), and self-reflexivity.

More importantly, rather than the identification of bounded cultural difference, one of the most powerful of Lévi-Strauss's ideas is the differential imbalance that indicates a tension between cultures. This is less praise for difference than a belief that transformations prevail over identity, structure, or the cultural system, all of which are based on morphodynamic and morphogenetic transformations. His magnum opus on the Mythologiques (LéviStrauss 1964, 1966, 1968, 1971) was massively open-ended and could never be completed, even after his small Mythologiques (Lévi-Strauss, 1985, 1991), since the possible permutation and transformation of mythical structures (armatures) are virtually never-ending agentive algorithms in a sort of Turing test of Amerindian mythology (Harkin 2019, 95). A point demonstrated by the Quadratura Americana suites (Desveaux 2001, 2007, 2017), essentially taking up where the Mythologiques left off. 
Thanks to his notion of transformation, the conception of structure decisively moved away from the binary logic of the linguistic model of differential elements, to which it is too often and obstinately reduced, in order to become a combinatorial analysis of these morphogenetic dynamics. Precisely, in his conceptualization of the generative engine of myths based on their own transformations, Lévi-Strauss staked the strongest claim to structural analysis as a scientific method that could be applied objectively, and which could reveal a level of reality encoded in the myths themselves. Far from a pseudo-mathematical mystification, as many Anglo-American anthropologists learnt it (Harkin 2019, 94), his structural method did actually originate in mathematics and it has gone on to be well received by modern scholars seeking to study culture and society by formal means (Santucci et al. 2011). In a broad sense, while the key categories that Lévi-Strauss developed are embodied in the anthropological objects he studied (myths and mythical networks), they have the potential to be usefully and critically applied to other domains if radically tweaked. Many studies show that the structural analysis initiated by Lévi-Strauss may innovatively account for the ways in which social relations are ever more mediated by and implicated in broader political processes (Asch 2005; Constable 2009; Marchart 2008). More importantly, Lévi-Strauss may be still a source of inspiration, sometimes even without proper acknowledgment, for thinking anthropologically about the interrelated contemporary ontological problems of the natural environment, the climatic regime, technology, economy, plantations, urbanization, identity, morality, and religion (Eriksen 2016; Latour 2015; Tsing 2015).

It could be argues that some aspects of Lévi-Strauss's theory, in particular the requirement of a boundary condition in canonical formalization, could be advanced as a workable methodology to help us build innovative anthropological approaches to agency and politics by contextualizing them within history, culture, and society. Boundary condition refers here to an empirical evidence from outside the realm of the myths being analysed, which Lévi-Strauss carefully identified in each case as crossing a boundary defined in geographic, linguistic, cultural, social, or whatever other terms. Boundary condition is also a formal mathematical concept, which LéviStrauss used in his further canonical formalisation to account for the morphogenetic and morphodynamic transformation of myths across the boundaries existing between one people and another. If we are now to develop a neo-structural model of canonical formalization based on discourse analysis and transformational morphodynamics, we may take lead from the abstract mathematical operations and the evolution rules of canonical transformations suggested by Lévi-Strauss for the structural study 
of myth, which make it necessary to isolate an analytical device as a boundary condition for mathematical validation.

Based on this epistemological insight, it can be argued that we may establish a more sophisticated approach following structural procedures of transformational analysis and formalization. While it may not hitherto have been expressed so directly, this means that we may be correct in asserting that from an empirical situation of social change, including social conflict, identity construction and ethnic identification, transcribed in canonical way, we can in theory deduce the possibly hidden reality of an external boundary, borderland existence, or border-crossing movement. As I have argued elsewhere, the notion of boundary condition could be expanded to account for the social morphodynamics of this reality, which would reveal itself in the form of a particular cultural ideology that might be discursively activated and amplified to act as a hidden agency of instrumental politics in actual sociocultural situations (Doja 2018).

Morphodynamic analyses of the empirical evidence about actual instances of women's agency, about family structures and fertility rates, about mass rapes in ethnic conflicts, or about identity transformations in the European context, provide some illustrative examples revealing the workings of the ideologies of gender, familism, honor and blood, and identity building respectively, as instrumental agency of hidden politics (Doja 2008c, 2010b, 2019). This is what I call 'cultural activism', which I define as a driving force external to a sociocultural situation and which may be thought, aptly in the case of family structures and fertility rates, as a kind of 'sociocultural viagra' to change or perpetuate the system (Doja 2010b, 361-362). The hidden reality so revealed is necessarily organized around a specific category of social hierarchy associated with the value of one identity element, human agency, and social action, but having inverse propositional characteristics to that element, course of action and agency. To put it the other way around, the morphodynamic formalization of cultural activism may allow us to identify instrumental ideologies and to anticipate new social change and identity construction as a result of the mediating logical operation of a boundary condition within the same sociocultural system or institutional frameworks, and we can be able to set off in their search and their appreciation.

If I am correct in these assumptions, we should consider that LéviStrauss's structural legacy provides us a new anthropologically informed movement in social theory that could account for the structural dynamics of change and conflict while revealing the hidden aspect of ideological agencies and political projects in the contemporary world. In particular, the conceptual aspects of Lévi-Strauss's later writings suggest a novel approach that requires to not rely only on surface observations of data 
and ethnography. Rather, critical analysis of empirical evidence and intersections of ethnography with both experiential understanding and structural formalization can yield new insights in the space between idiographic and nomothetic understandings of culture, politics, and ideology.

\section{Notes}

1. See also his Lecture at the Japan Productivity Centre in 1983 (Lévi-Strauss 2001b).

2. Incidentally, all days along the Paris COP21 of December 2015 on global climate agreements, I witnessed in the French TV media the constant broadcast of a short sequence of images cut from an innovative pedagogical project and ambitious experiment staged by Bruno Latour and his students to address climate change as part of Paris COP21 negotiations (one variant can be watched in Bornstein 2015, min.03:35-04:15). Without acknowledgment, the cut out images showed the intended creation of a ritual and symbolic atmosphere for healthy negotiations that reproduced with a striking similarity Lévi-Strauss's insights formulated in his first Japanese Lecture, showing the importance that some societies attach to ritual and symbolism in preparing the ground for negotiations, agreements, and decisions (Lévi-Strauss 2001b).

3. The English translation "technique of making strange" (p. 31) is oddly inadequate.

4. Maurice Blanchot, "L’homme au point zéro", L’Amitié, Paris: Gallimard (1971, 87). (English translation: Stanford University Press 1997, 74).

5. See also his last address at Unesco (Lévi-Strauss 2007).

6. According to Pierre Maranda in an essay discussing the impact of structural analysis presented at the University of British Columbia. Quoted in: Marie Mauzé, Michael Harkin, and Sergei Kan, eds. Coming to shore: Northwest Coast ethnology, traditions, and visions (Lincoln: University of Nebraska Press, 2004), p. 90.

7. Reported answer by the Harvard sociocultural anthropology coordinator in Fall 2017. Personal communication on November 8, 2017, from Gary Urton, the then Chair of Anthropology Department at Harvard University, also confirmed in personal communication a few days later by Michael Herzfeld, another senior anthropologist at Harvard.

\section{ORCID}

Albert Doja (D) http://orcid.org/0000-0001-5378-8362

\section{References cited}

Asch, Michael

2005 Lévi-Strauss and the Political: The Elementary Structures of Kinship and the

Resolution of Relations between Indigenous Peoples and Settler States. Journal of the

Royal Anthropological Institute 11(3):425-444. doi: 10.1111/j.1467-9655.2005.00244.x.

Barthes, Roland

1953 Le degré zéro de l'écriture. Paris: Seuil [Eng. Writing degree zero, New York: Hill-

Wang, 2012].

Bornstein, David

2015 Le climat: thêâtre des négociations. Paris: Films-de-l'Air. https://vimeo.com/143874181. 
Butler, Judith

2004 Undoing Gender. London/NewYork, NY: Routledge.

Cerni, Paula

2013 Claude Lévi-Strauss Stays the Mighty Hand of History, at Least for a Moment.

PopMatters, 25/07/2013. https://www.popmatters.com/173252-anthropology-confrontsetc-2495742998.html.

Constable, Nicole

2009 The Commodification of Intimacy: Marriage, Sex, and Reproductive Labor.

Annual Review of Anthropology 38(1):49-64. doi: 10.1146/annurev.anthro.37.081407. 085133.

Desveaux, Emmanuel

2001 Quadratura Americana: Essai d'anthropologie lévi-straussienne. Geneve, Switzerland: Georg.

Desveaux, Emmanuel

2007 Spectres de l'anthropologie: Suite Nord-américaine. Montreuil, France: Lieux-d'etre.

Desveaux, Emmanuel

2017 La parole et la substance: Anthropologie comparée de l'Amèrique et de l'Europe.

Paris: Indes-Savantes.

Doja, Albert

2005 The Advent of Heroic Anthropology in the History of Ideas. Journal of the History of Ideas 66(4):633-650. doi: 10.1353/jhi.2005.0054.

Doja, Albert

2006a The Kind of Writing: Anthropology and the Rhetorical Reproduction of Post-

Modernism. Critique of Anthropology 26(2):157-180. doi: 10.1177/0308275X06064993.

Doja, Albert

2006b The Predicament of Heroic Anthropology. Anthropology Today 22(3):18-22. doi: 10.1111/j.1467-8322.2006.00439.x.

Doja, Albert

2006c The Shoulders of Our Giants: Claude Lévi-Strauss and His Legacy in Current

Anthropology. Social Science Information 45(1):79-107. doi: 10.1177/ 0539018406061104.

Doja, Albert

2007 Creative Misreading and Bricolage Writing: A Structural Appraisal of a

Poststructuralist Debate. Portuguese Review of the History of the Book 11(22):89-104.

Doja, Albert

2008a Claude Lévi-Strauss at His Centennial: Toward a Future Anthropology. Theory,

Culture \& Society 25(7-8):321-340. doi: 10.1177/0263276408097810.

Doja, Albert

2008b From Neolithic Naturalness to Tristes Tropiques: The Emergence of Lévi-Strauss's

New Humanism. Theory, Culture \& Society 25(1):77-100. doi: 10.1177/ 0263276407090015.

Doja, Albert

2008c Instrumental Borders of Gender and Religious Conversions in the Balkans.

Religion, State \& Society 36(1):55-63. doi: 10.1080/09637490701809738.

Doja, Albert

2010a Claude Lévi-Strauss (1908-2009): The Apotheosis of Heroic Anthropology.

Anthropology Today 26(5):18-23. doi: 10.1111/j.1467-8322.2010.00758.x. 
Doja, Albert

2010b Fertility Trends, Marriage Patterns, and Savant Typologies in Albanian context. Journal of Family History 35(4):346-367. doi: 10.1177/0363199010381045.

Doja, Albert

2018 Social Morphodynamics: Mapping Identity Transformations, Cultural Encounters, and the Evolution of Core Values. Social Epistemology Review and Reply Collective $7(1): 14-25$.

Doja, Albert

2019 Politics of Mass Rapes in Ethnic Conflict: A Morphodynamics of Raw Madness and Cooked Evil. Crime Law and Social Change 71(5):541-580. doi: 10.1007/s10611-0189800-0.

Doja, Albert

2020 Celebrations of Lévi-Strauss's Heroic Legacy. The Journal of the Royal Anthropological Institute 26(4). https://doi.org/10.1111/1467-9655.13366.

D’Onofrio, Salvatore

2018 Lévi-Strauss Face à la Catastrophe. Milan, Paris: Mimesis.

Eriksen, Thomas-Hylland

2016 Overheating: An Anthropology of Accelerated Change. London: Pluto.

Fassin, Eric

1999 Voix de l'expertise et silences de la science dans le débat démocratique. Au-delà du

PaCS: L'expertise familiale à l'épreuve de l'homosexualité. Pp. 87-110. Paris: PUF. doi:

10.3917/puf.borri.2001.02.0087.

Favret-Saada, Jeanne

2000 La-pensée-Lévi-Strauss. Journal des Anthropologues 82-83:53-70. doi: 10.4000/jda. 3278.

Foster, Adam

2017 Review of We are all cannibals. To Be Decided 2:121-123. http://tbd-journal.com/ s/Foster_Review_WeAreAllCannibals_TBDVol2MonstersandBeasts.pdf.

Foucault, Michel

1966 Les Mots et Les Choses. Paris: Gallimard. [Eng. The Order of Things. London: Tavistock 1970].

Geertz, Clifford

1967 Cerebral Savage: On the Work of Claude Lévi-Strauss. Interpretation of Cultures.

Pp. 345-359. New York, NY: Basic-Books.

Godelier, Maurice

2013 Lévi-Strauss. Paris: Seuil. [Eng. London: Verso, 2018].

Harkin, Michael

2019 Lévi-Strauss: Two Lives. Reviews in Anthropology 48(2):88-102. doi: 10.1080/ 00938157.2019.1644468.

Hayes, Nelson, and Tanya Hayes, eds.

1970 Claude Lévi-Strauss: The Anthropologist as Hero. Cambridge: MIT Press.

Hayot, Eric

2013 Through the Mirror: Claude Lévi-Strauss in Japan. Los Angeles Review of Books. 14/04/

2013. https://lareviewofbooks.org/article/through-the-mirror-claude-levi-strauss-in-japan/.

Henaff, Marcel

2011 Adieu à la Structure. Esprit (8):114-119. doi: 10.3917/espri.1108.0114.

Jakobson, Roman, and Claude Lévi-Strauss

2018 Correspondance, 1942-1982. Paris: Seuil. 


\section{Keck, Frédéric}

2019 Lévi-Strauss: la nature au point zéro. Terrestres. 8. 13/10/2019. https://www.terrestres.org/2019/10/13/levi-strauss-la-nature-au-point-zero/

Kristeva, Julia

2016 Review of We are all Cannibals. Columbia University Press Reviews. http://cup. columbia.edu/book/we-are-all-cannibals/9780231170680.

Kuper, Adam

2013 Out of Eden. Anthropology of this Century, 8. http://aotcpress.com/articles/eden/

Laplantine, François

2012 Note critique. Anthropologie et Sociétés 36(1-2):297-302. doi: 10.7202/1011729ar.

Latour, Bruno

2015 Face à Gaïa: huit conférences sur le nouveau régime climatique. Paris: Découverte.

[Eng. Cambridge: Polity, 2017].

Launay, Robert

2013 Is Lévi-Strauss Still Good to Think? Reviews in Anthropology 42(1):38-49. doi: 10.

1080/00938157.2013.765762.

Leach, Edmund

1964 Telstar et les aborigènes ou la Pensée sauvage. Annales Histoire Sciences Sociales 19(6):1100-1116. doi: 10.3406/ahess.1964.421261.

Leach, Edmund

1970 Claude Lévi-Strauss. London: Fontana/Collins.

Lévi-Strauss, Claude

1950 Introduction à l'oeuvre de Marcel Mauss. Paris: PUF. [Engl. London: Routledge, 1987].

Lévi-Strauss, Claude

1955 Tristes Tropiques. Paris: Plon. [Eng. London: Cape, 1973].

Lévi-Strauss, Claude

1958 Anthropologie structurale. Paris: Plon. [Eng. New York: Basic Books, 1963].

Lévi-Strauss, Claude

1960 La structure et la forme. Anthropologie structurale deux. Pp.139-173. Paris: Plon.

Lévi-Strauss, Claude

1962 La pensée sauvage. Paris: Plon. [Eng. The Savage Mind, London: Weidenfeld \&

Nicolson, 1966.

Lévi-Strauss, Claude

1964 Le Cru et le Cuit. Paris: Plon. [Eng. New York: Harper \& Row, 1969].

Lévi-Strauss, Claude

1966 Du miel aux cendres. Paris: Plon. [Eng. New York: Harper \& Row, 1973].

Lévi-Strauss, Claude

1967 Les structures élémentaires de la parenté. 2nd ed. Paris/Hague: Mouton. [Eng.

Boston: Beacon Press, 1969].

Lévi-Strauss, Claude

1968 L'origine des manières de table. Paris: Plon. [Eng. New York: Harper \& Row, 1978].

Lévi-Strauss, Claude

1971 L'homme nu. Paris: Plon. [Eng. New York: Harper \& Row, 1981].

Lévi-Strauss, Claude

1985 Lapotière jalouse. Paris: Plon. [Eng. University of Chicago Press, 1988].

Lévi-Strauss, Claude

1991 Histoire de lynx. Paris: Plon. [Eng. University of Chicago Press, 1995]. 
Lévi-Strauss, Claude

1994 Saudades do Brasil. Paris: Plon. [Eng. University of Washington Press, 1995].

Lévi-Strauss, Claude

2001a. Review of "Frank Salomon \& Stuart Schwartz, eds., The Cambridge History of the Native Peoples of the Americas (Cambridge University Press, 1999)." L'Homme: Revue Française d'Anthropologie 41(158-159):439-442.

Lévi-Strauss, Claude

2001b Productivité et Condition Humaine. Études rurales (159-160):129-144. doi: 10. 4000/etudesrurales.73.

Lévi-Strauss, Claude

2002 Race et histoire/Race et culture. Paris: UNESCO/Albin-Michel.

Lévi-Strauss, Claude

2007 Unesco at 60. Diogenes 54(3):5-10. doi: 10.1177/0392192107081172.

Lévi-Strauss, Claude

2011a L'anthropologie face aux problèmes du monde moderne. Paris: Seuil. [Eng. Harvard University Press, 2013].

Lévi-Strauss, Claude

2011b L'autre face de la lune. Paris: Seuil. [Eng. Belknap Press, 2013].

Lévi-Strauss, Claude

2013 Nous sommes tous des cannibales. Paris: Seuil. [Eng. Columbia University Press, 2016].

Lévi-Strauss, Claude

2015 Chers tous deux: Lettres à ses parents, 1931-1942. Paris: Seuil.

Lévi-Strauss, Claude

2016a De Montaigne à Montaigne. Paris: EHESS. [Eng. University of Minnesota Press, 2019].

Lévi-Strauss, Claude

2016b Le Père Noël supplicié. Paris: Seuil. [Eng. transl. included in "We are all cannibals"].

Lévi-Strauss, Claude

2019 Anthropologie structurale zéro. Paris: Seuil.

Loyer, Emmanuelle

2015 Lévi-Strauss. Paris: Flammarion. [Eng. Cambridge: Polity, 2018].

Marchart, Oliver

2008 Ungesellschaftliche Gesellschaftlichkeit: Exklusion und Antagonismus bei LéviStrauss. Soziale Systeme 14(2):370-396. doi: 10.1515/sosys-2008-0214.

McLennan, Matthew

2016 Review of "We are all Cannibals." Symposium. 23/11/2016. https://www.c-scp.org/ 2016/11/23/claude-levi-strauss-we-are-all-cannibals-and-other-essays.

Ohnuki-Tierney, Emiko

2014 Wild Pansies in Japan. American Anthropologist 116(2):434-436. doi: 10.1111/ aman.12090_1.

Robcis, Camille

2013 Lévi-Strauss's Structuralist Social Contract. Yale French Studies 2013 (123):145-165.

Rubin, Gayle

1975 Traffic in Women: Notes on the Political Economy of Sex. Toward an Anthropology of Women. Pp. 157-210. New York, NY: Monthly-Review-Press.

Santucci, Jean-François, Emmanuelle De Gentili, and Ghjasippina Thury-Bouvet 2011 Discrete Event Modeling and Simulation of the Mythical Thought Morphodynamics 
involved in Claude Lévi-Strauss Structural Analysis. In Handbook of Research on Culturally-Aware Information Technology: Perspectives and Models. Emmanuel Blanchard and Danièle Allard, eds. Pp. 152-178. Hershey, NY: Information Science Reference. https://doi.org/10.4018/978-1-61520-883-8.ch008

Sontag, Susan

1963 A Hero of Our Time. New York Review of Books 1(7). https://www.nybooks.com/ articles/1963/11/28/a-hero-of-our-time/

Strathern, Marilyn

1992 Reproducing the Future. New York, NY: Routledge.

Strathern, Marilyn

2018 Review of We are all Cannibals. Common Knowledge 24(2):313-314. doi: 10.1215/ $0961754 \mathrm{X}-4362547$.

Strong, Thomas

2002 Kinship Between Judith Butler and Anthropology. Ethnos 67(3):401-418. doi: 10. 1080/0014184022000031220.

Tsing, Anna

2015 The Mushroom at the End of the World: On the Possibility of Life in Capitalist Ruins. Princeton, NJ: Princeton University-Press.

Wiseman, Boris, ed.

2009 Cambridge companion to Lévi-Strauss. Cambridge: Cambridge University Press.

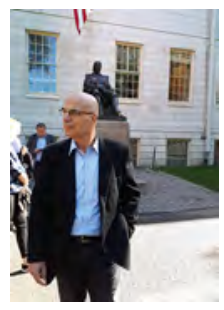

ALBERT DOJA is University Professor of Anthropology at the University of Lille, France, and Member of the National Academy of Sciences, Albania. He hold a Ph.D. in Social Anthropology from the Paris School of Advanced Studies in Social Sciences (EHESS) and a Professorial accreditation (Habilitation à Diriger des Recherches) from Paris Descartes University, Sorbonne. A former Visiting Research Scholar at Harvard University and Honorary Fellow of the Department of Anthropology at University College London, he has held several academic positions in France, USA, Britain, Ireland, and Albania, lectured in social anthropology and conducted extensive fieldwork research in many other countries. (https://pro.univ-lille.fr/en/albert-doja/) 